\title{
ASSESSMENT OF PLANETARY BOUNDARY LAYER SCHEMES OF THE WRF-CHEM MODEL IN THE SIMULATION OF CARBON MONOXIDE DISPERSION IN THE URBAN AREA OF QUITO, ECUADOR
}

\author{
RENE PARRA \\ Instituto de Simulación Computacional, Colegio de Ciencias e Ingeniería, \\ Universidad San Francisco de Quito, Ecuador
}

\begin{abstract}
In tandem with emissions, the dynamics of the Planetary Boundary Layer (PBL) strongly define the concentration of pollutants in the atmosphere. The PBL parameterization schemes of numerical models need to be assessed to identify which one provides the best performance, especially in places with such complex topography as the Andean region of Ecuador. For this purpose, the dispersion of carbon monoxide (CO) in Quito (northern Ecuador, 2800 masl) during October 2014 was simulated using the Eulerian Weather Research and Forecasting with Chemistry (WRF-Chem V3.2) model, under 5 PBL schemes: 1. Yonsei University, YSU; 2. Mellor-Yamada-Janjic, MYJ; 3. Quasi-Normal Scale Elimination, QNSE; 4. Mellor-Yamada Nakanishi and Niino Level 2.5, MYN; and 5. BouLac PBL, BL. Simulations were performed using a domain with high spatial resolution $(1 \mathrm{~km})$ and results were compared with records from five air quality stations. On average, the percentage of days positively captured by modeling, for maximum $\mathrm{CO}$ concentrations over both 1-hour and 8-hour periods, was highest for QNSE (78.9\%) and MYJ (76.8\%), both 1.5 order local schemes. This assessment should be done for other periods, pollutants and meteorological variables.
\end{abstract}

Keywords: Distrito Metropolitano de Quito, PBL, local scheme, nonlocal scheme, modeling performance, $C O$ dispersion.

\section{INTRODUCTION}

Interactions between air pollutant emissions and meteorology define air quality levels. Among the meteorological components, the dynamics of the Planetary Boundary Layer (PBL) strongly influence in the concentration of pollutants.

The PBL is the bottom part of the atmosphere, which is influenced directly by the Earth's surface, and responds with a timescale of one hour or less [1]. It experiences a daily cycle of temperature, humidity, wind and pollution variation [2]. The PBL depth can vary from a few tens of meters early in the day, to several kilometers by midday [3], producing a changing volume of atmosphere to disperse pollutants.

Turbulence is the dominant mechanism by which surface forcing is transmitted throughout the PBL. Because turbulence causes mixing, the PBL becomes homogenized [2]. Turbulence operates on scales that cannot be explicitly represented on grid scales and time steps used in most weather mesoscale models [4]. Hence, its effects are expressed in modeling trough PBL parameterization schemes.

There are two major components by which turbulence is represented in numerical weather models: 1) the order of turbulence closure, 2) the use of a local or nonlocal mixing approach.

The representation of PBL schemes decomposes the variables of the equation of motion into mean and perturbation components. The mean components show the time-averaged conditions of the background atmosphere. The perturbation components show turbulent fluctuations from the background mean state. Equations representing turbulence contain 
unknown terms, and these always are of one order above the known terms. For this reason, turbulence closure requires empirically relating the unknown terms of moment $n+1$ to lower-moment known terms. This is referred to as nth-order turbulence closure, where $\mathrm{n}$ is an integer [3]. Some schemes present a 1.5-order of closure because they use second-order moments for some variables, and first-order moments for others.

Moreover, local schemes consider the influence only of the adjacent layers to a given cell and neglect the influence of large eddies; and nonlocal schemes use multiple vertical layers to a given cell, considering the superposition of both large and small eddies.

The influence of PBL schemes has been studied mainly in simulating meteorology (e.g. [4]-[6]) and air quality in a lesser extent [7]. PBL schemes need to be assessed, especially in places where turbulent processes are particularly complex, as the Distrito Metropolitano de Quito (DMQ) (Fig. 1), which is located near the Equator (northern Andean region of Ecuador). It has a complex topography, with heights between 800 and 4000 masl.

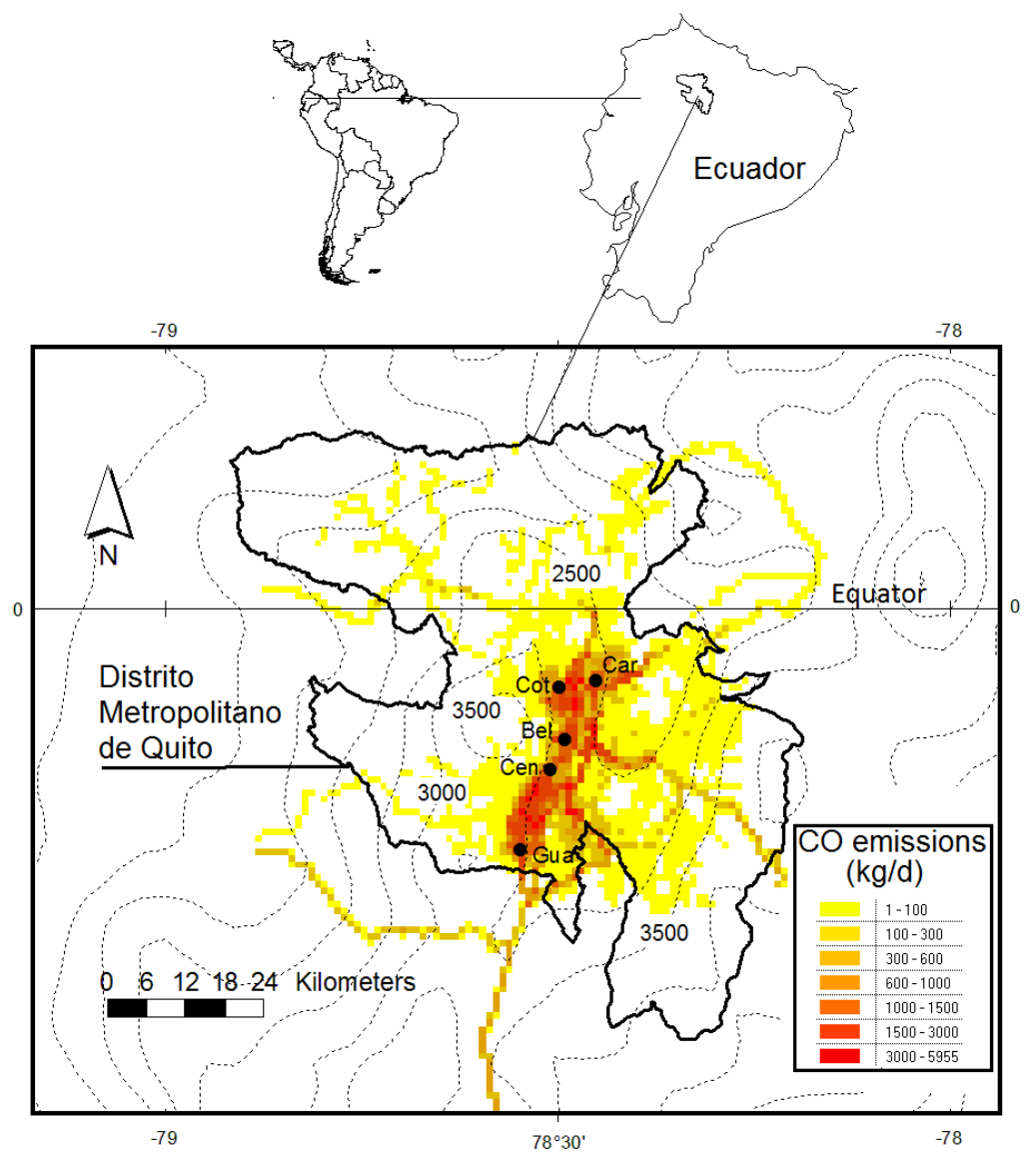

Figure 1: Location of the Distrito Metropolitano de Quito (DMQ) and of the 5 air quality automatic stations used for this assessment: Car (Carapungo), Cot (Cotocollao), Bel (Belisario), Cen (Centro Histórico), Gua (Guamani). Colors show the $\mathrm{CO}$ emission $(\mathrm{kg} / \mathrm{d})$ from on-road traffic during a typical weekday for 2014. Dashed lines depict topography (masl). 
On-road traffic is the main source of carbon monoxide (CO) in the DMQ. According to emission inventory in 2007, this sector contributed $98 \%$ of CO [8], and these emissions are mainly produced in the urban area of Quito (2800 masl), the capital of Ecuador. Traffic varies between weekdays and weekends, both in timing and magnitude (Figs 2 and 3) [9].

$\mathrm{CO}$ is relatively nonreactive [10], with a two-month mean lifetime [11], so it can be used as tracer in assessing the PBL schemes through numerical modeling. Less computational time is needed using $\mathrm{CO}$ in comparison with simulations including reactive pollutants.

\section{METHOD}

Numerical simulations of CO dispersion were done for the period of October 1-28, 2014, using hourly $\mathrm{CO}$ emission maps generated from the on-road traffic emission inventory from Quito during the year 2012 [12] and considering traffic variations between weekdays and weekends [9]. CO emission files were used into the Eulerian 3D model Weather Research and Forecasting with Chemistry (WRF-Chem V3.2) [13]. WRF is a 3-D last-generation non-hydrostatic model used for meteorological forecasting and weather research. It is a fully compressible model that solves the equations of atmospheric motion, with applicability to global, mesoscale, regional and local scales. WRF has the option (WRF-Chem) to simulate the coupling between dynamics, radiation, and chemical transport of pollutants.

Meteorological simulations were done using a master domain of $100 \times 100$ cells, each of $27 \times 27 \mathrm{~km}$; and three nested subdomains. The third subdomain has $121 \times 121$ cells of $1 \mathrm{~km}$ by side each one, and 35 vertical levels. This subdomain covers the region of the DMQ (Fig. 1). Initial and boundary meteorological conditions were obtained using NCEP FNL (Final) Operational Global Analysis data [14]. For the inner domain, the option for CO dispersion into WRF-Chem was activated.

October was selected for this assessment, because on-road traffic intensity during this month implies representative emissions associated with normal socioeconomic activities in the DMQ.

WRF-Chem was configured using the following physical parameterizations [15]: the single-moment 5-class scheme for microphysics, the rapid radiative transfer model ( $\mathrm{rrtm})$ for long-wave radiation, the Goddard scheme for short-wave radiation, the Noah model for land surface, and Grell 3d ensemble scheme as cumulus option.

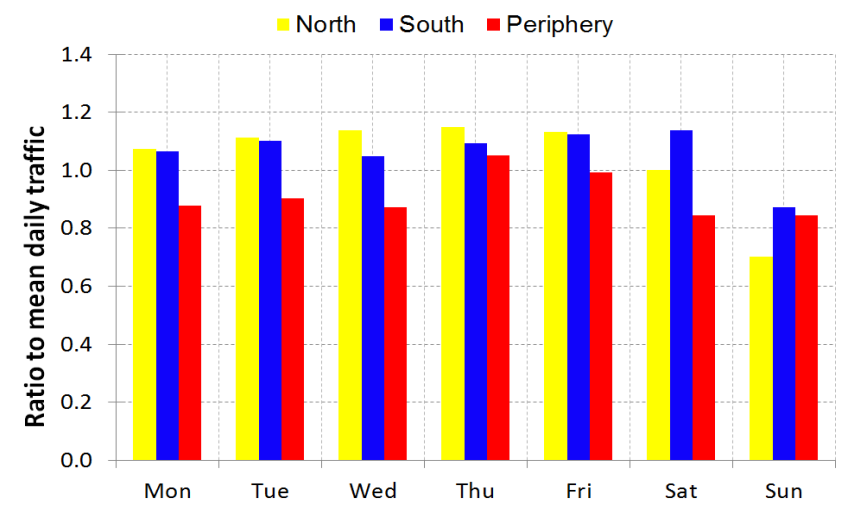

Figure 2: Variation of traffic flow by day of the week in comparison with the mean daily traffic in the Distrito Metropolitano de Quito. Year 2012 [9]. 


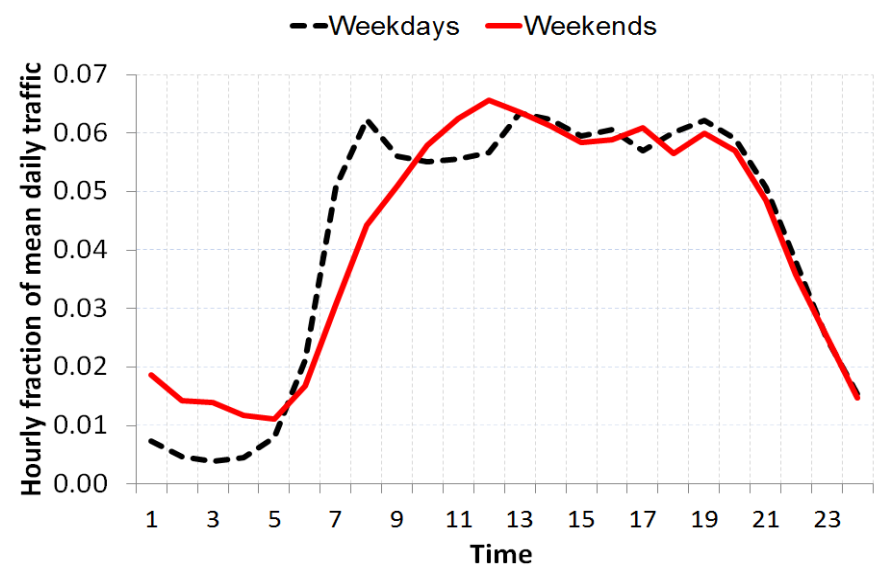

Figure 3: Mean daily profiles of hourly traffic for weekdays and weekends in the Distrito Metropolitano de Quito. Year 2012 [9].

Simulations were done for 5 PBL schemes. Table 1 shows a summary of their features. Additionally, a sixth scenario was built, corresponding to the ensemble average results of these 5 PBL schemes.

Table 1: WRF-Chem V3.2 PBL schemes used for CO numerical simulations in the DMQ during October of 2014.

\begin{tabular}{|c|l|l|l|l|l|}
\hline & Scheme & Nomenclature & $\begin{array}{l}\text { Order of turbulence } \\
\text { closure }\end{array}$ & $\begin{array}{l}\text { Mixing } \\
\text { approach }\end{array}$ & Reference \\
\hline 1 & Yonsei University & YSU & First & Nonlocal & {$[16]$} \\
\hline 2 & Mellor-Yamada-Janjic & MYJ & 1.5 & Local & {$[17]$} \\
\hline 3 & $\begin{array}{l}\text { Quasi-Normal Scale } \\
\text { Elimination }\end{array}$ & QNSE & 1.5 & Local & {$[18]$} \\
\hline 4 & $\begin{array}{l}\text { Mellor-Yamada } \\
\text { Nakanishi and Niino } \\
\text { Level 2.5 }\end{array}$ & MYN & 1.5 & Local & {$[19]$} \\
\hline 5 & BouLac PBL & BL & 1.5 & Local & {$[20]$} \\
\hline
\end{tabular}

For each PBL scheme, performance was assessed by the number of days positively captured in modeling both the maximum 1-hour and 8-hour $\mathrm{CO}$ means, concentrations with guidelines by the World Health Organization [21]. For this purpose, days were considered "positive modeled" if the maximum deviation of observed and modeled concentrations was $50 \%$. This criterion is consistent with the uncertainty definition and modeling quality objectives under the European Union's Air Quality Directive [22].

\section{RESULTS}

As an example, Fig. 4 shows the modeled results of PBL and $\mathrm{CO}$ concentrations for October 17, 2014 (weekday, QNSE PBL scheme), from 06h00 to 12h00. For these hours, higher CO concentrations were computed at $08 \mathrm{~h} 00$, when peak on-road traffic emissions (Fig. 3) were injected while PBL depths still were low. At 12h00, CO levels decreased due to the increment of the PBL depths and reduction of emissions. 

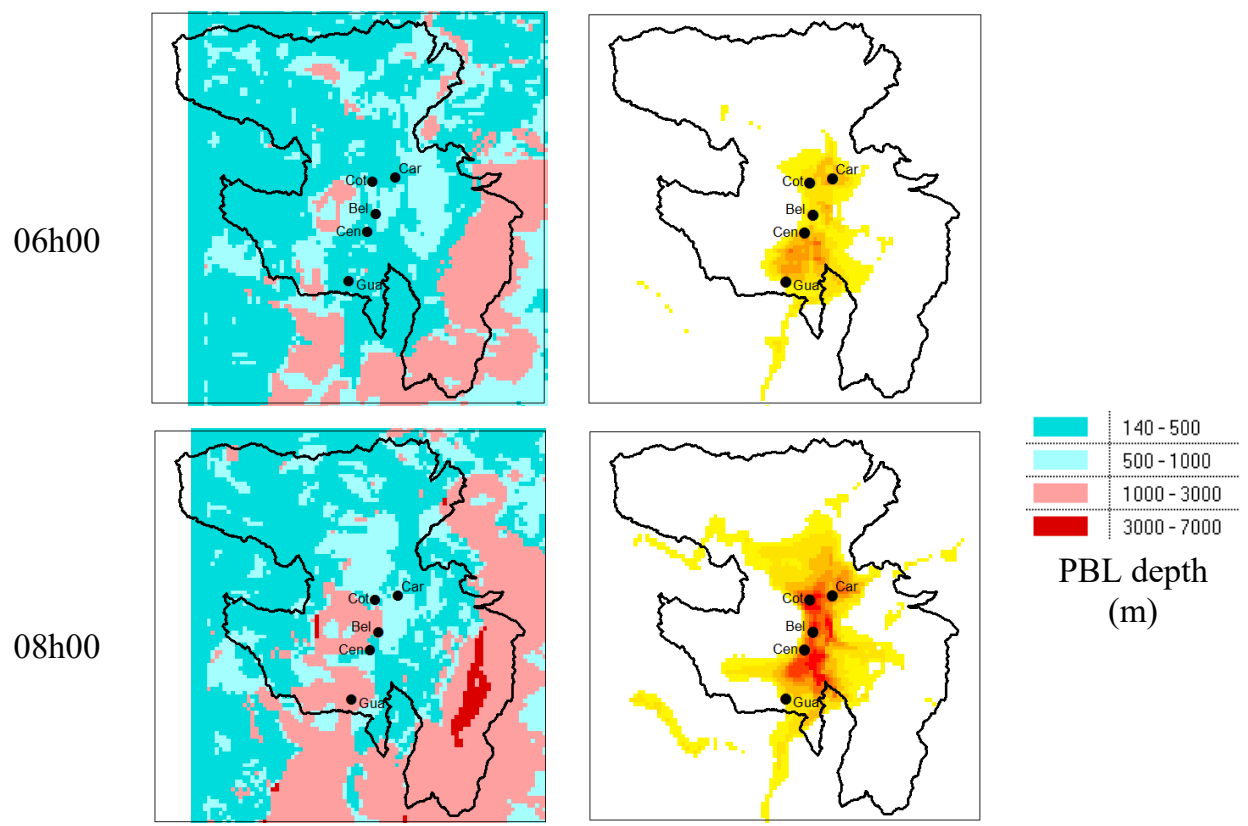

PBL depth

(m)
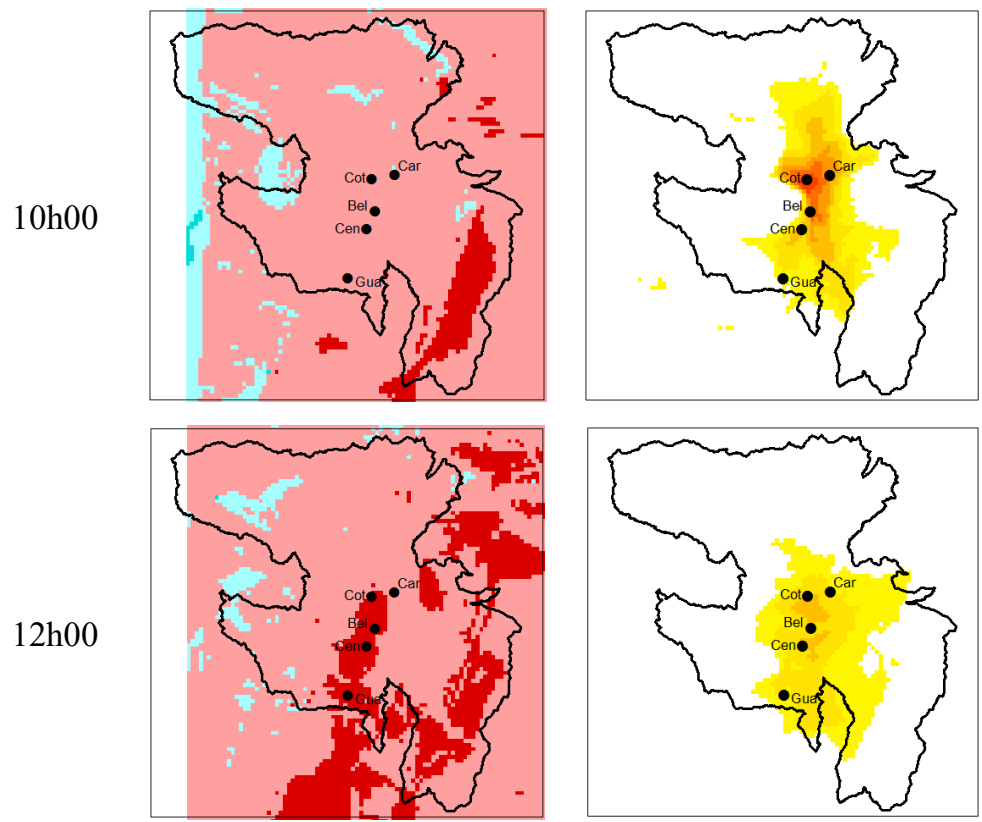

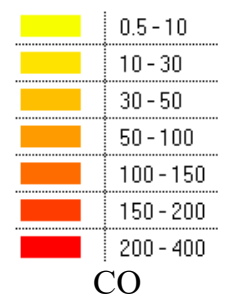

concentration

$\left(\mathrm{mg} \mathrm{m}^{-3}\right)$

Figure 4: PBL depth and CO concentration obtained by modelling. 17 Oct. 2014: 06h00, 08h00, $10 \mathrm{~h} 00$ and $12 \mathrm{~h} 00$ (local time). QNSE PBL scheme.

Although the modeled hourly results for all the PBL schemes followed the same pattern as observed $\mathrm{CO}$ concentrations (Fig. 5), the performance was different. QNSE and ensemble average scenario, with $79.3 \%$ and $77.1 \%$ of days respectively, showed the highest 
percent of days positively captured in modeling the maximum 1-hour mean CO concentrations (Table 2, Fig. 6). Nevertheless, in modeling the 8-hour mean CO concentrations, the ensemble average scenario showed the highest performance $(85 \%)$ and 4 schemes (QNSE: 78.6\%, MYJ: 77.9\%, MYN: 77.1\%, YSU: 75.7\%) showed percentages higher than $75 \%$ (Table 2 ).

On average, the percentage of days positively captured both for maximum 1-hour and 8hour mean CO concentrations was highest for QNSE (78.9\%) and MYJ (76.8\%) schemes.

Table 2: Percentage of days positively modeled (uncertainty $<50 \%$ ).

\begin{tabular}{|c|c|c|c|c|c|c|}
\hline \multicolumn{7}{|c|}{ Maximum 1-hour mean CO concentrations } \\
\hline \multirow[b]{2}{*}{ Station } & \multicolumn{6}{|c|}{ PBL scheme } \\
\hline & $1 \mathrm{YSU}$ & $2 \mathrm{MYJ}$ & 3 QNSE & 4 MYN & $5 \mathrm{BL}$ & 6 Ensemble \\
\hline Car & 60.7 & 82.1 & 85.7 & 71.4 & 75.0 & 85.7 \\
\hline Cot & 64.3 & 60.7 & 71.4 & 82.1 & 39.3 & 60.7 \\
\hline $\mathrm{Bel}$ & 85.7 & 78.6 & 82.1 & 85.7 & 64.3 & 82.1 \\
\hline Cen & 67.9 & 67.9 & 64.3 & 50.0 & 89.3 & 71.4 \\
\hline Gua & 53.6 & 89.3 & 92.9 & 82.1 & 78.6 & 85.7 \\
\hline Average 1-hour & 66.4 & 75.7 & 79.3 & 74.3 & 69.3 & 77.1 \\
\hline \multicolumn{7}{|c|}{ Maximum 8-hour mean CO concentrations } \\
\hline \multirow[b]{2}{*}{ Station } & \multicolumn{6}{|c|}{ PBL scheme } \\
\hline & $1 \mathrm{YSU}$ & $2 \mathrm{MYJ}$ & 3 QNSE & 4 MYN & $5 \mathrm{BL}$ & 6 Ensemble \\
\hline \begin{tabular}{|l|} 
Car \\
\end{tabular} & 67.9 & 78.6 & 75.0 & 67.9 & 92.9 & 85.7 \\
\hline Cot & 82.1 & 92.9 & 92.9 & 96.4 & 35.7 & 85.7 \\
\hline Bel & 78.6 & 71.4 & 75.0 & 78.6 & 35.7 & 67.9 \\
\hline Cen & 71.4 & 71.4 & 71.4 & 75.0 & 82.1 & 96.4 \\
\hline Gua & 78.6 & 75.0 & 78.6 & 67.9 & 78.6 & 89.3 \\
\hline Average 8-hour & 75.7 & 77.9 & 78.6 & 77.1 & 65.0 & 85.0 \\
\hline Global average & 71.1 & 76.8 & 78.9 & 75.7 & 67.1 & 81.1 \\
\hline
\end{tabular}

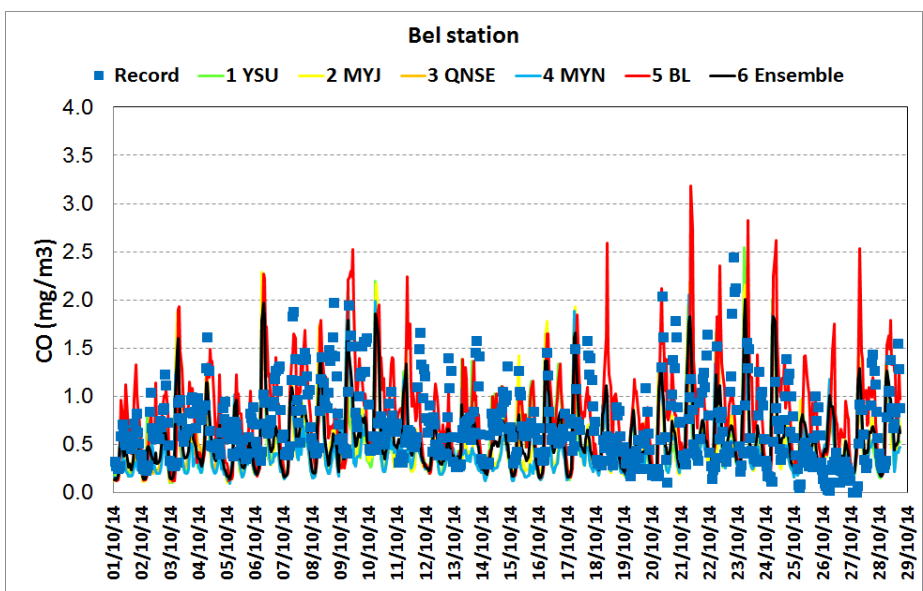

Figure 5: Hourly CO concentrations $\left(\mathrm{mg} \mathrm{m}^{-3}\right)$ for Bel (center-north) station. Blue squares show records. Lines show modeled concentrations using different PBL schemes. 


\section{Cot station}

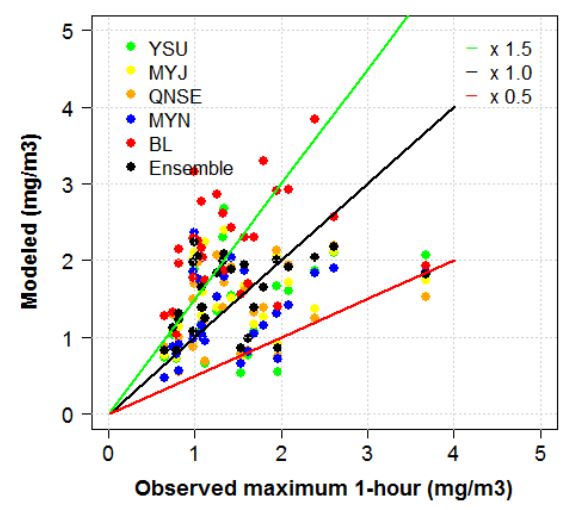

Cen station

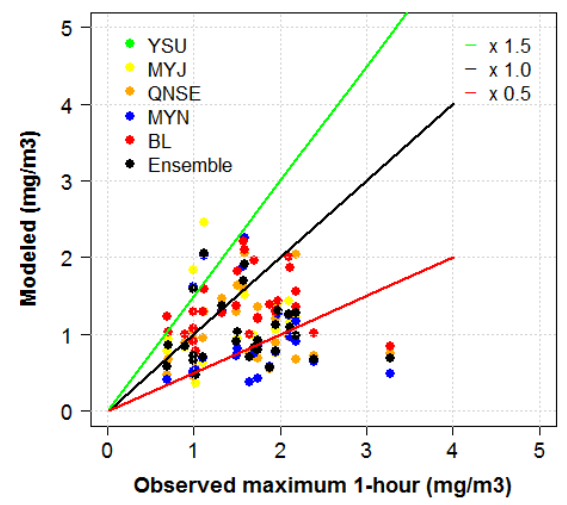

Gua station

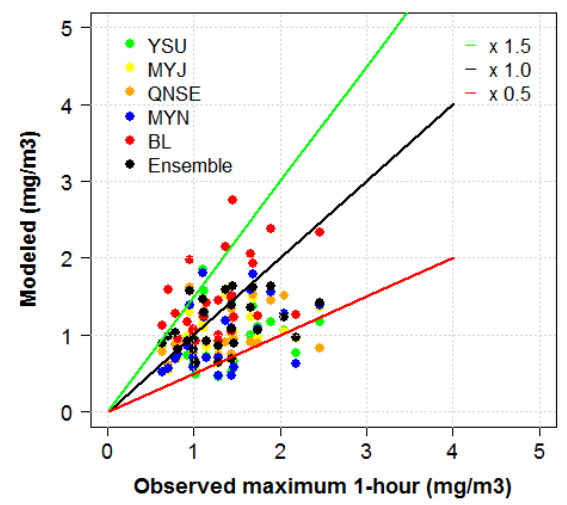

\section{Cot station}

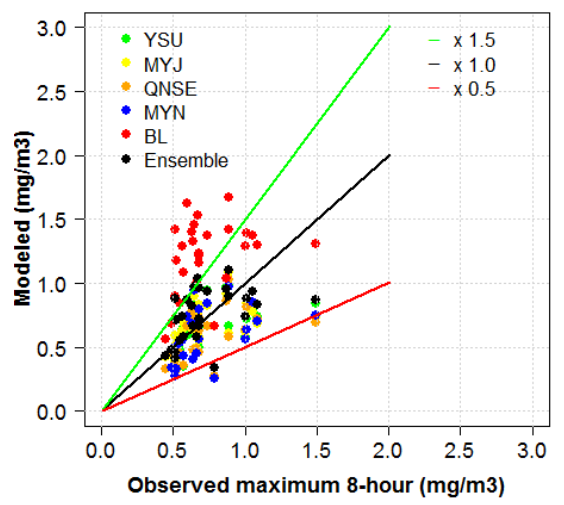

Cen station

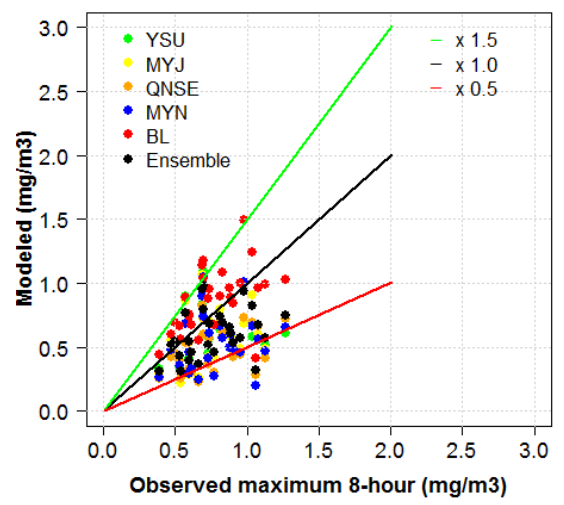

\section{Gua station}

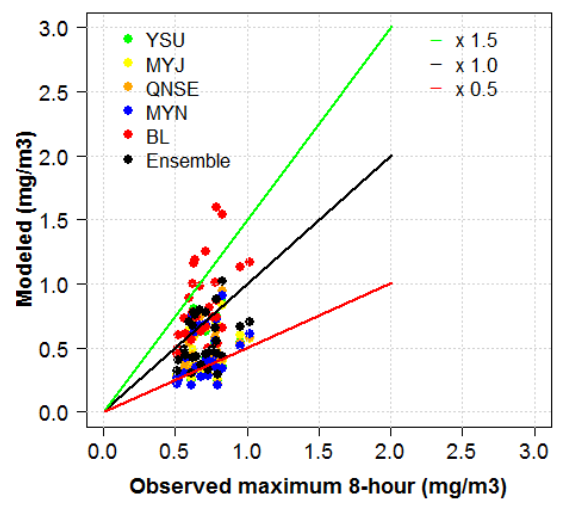

Figure 6: Comparison between observed and modeled CO concentrations: Cot station (north), Cen station (center), Gua station (south). Dots inside the green and red lines correspond to pairs with uncertainty of $50 \%$. 


\section{DISCUSSION AND CONCLUSIONS}

In this assessment, QNSE and MYJ, both 1.5 order local schemes, showed the best performance in modeling the $\mathrm{CO}$ dispersion in the urban area of Quito.

QNSE is one of the PBL schemes proposed as part of the Reference Configuration (RC) for the WRF V3.2 (Table 3). Based on feedback from the WRF user community and from meteorological data, $\mathrm{RC}$ is a particular combination of parameters, recommended as guide for both research and operational implementation [23].

Although YSU is the other PBL scheme of the RC for WRF V3.2, in this assessment it reached a global performance of $71.1 \%$, lower than the performance of QNSE (78.9\%), MYJ (76.8\%), and MYN (75.7\%) schemes.

QNSE also was identified as one of the schemes which appeared superior in capturing the lower PBL structure in the assessment in the Great Salt Lake Desert (United States) by Dimitrova et al. (2015) [6] (Table 3). Nevertheless, MYJ, MYN and YSU schemes showed the best performance in meteorological assessments done for the Athens (Greece) and Kalpakkam (India) regions (Table 3).

YSU, the other PBL scheme of the RC for WRF V3.2, showed greatest agreement with observations, in the intercomparison of $\mathrm{O} 3$ modeling in Houston (United States) [7].

Table 3: Comparison with other assessments of PBL's schemes.

\begin{tabular}{|c|c|c|c|c|c|c|}
\hline \multirow{2}{*}{$\begin{array}{l}\text { Reference or } \\
\text { case }\end{array}$} & \multirow[b]{2}{*}{ Latitude } & \multirow[b]{2}{*}{ Region } & \multirow{2}{*}{$\begin{array}{l}\text { Period for } \\
\text { assessment }\end{array}$} & \multicolumn{2}{|c|}{ Data for assessment } & \multirow{2}{*}{$\begin{array}{l}P B L \\
\text { Scheme with } \\
\text { best } \\
\text { performance }\end{array}$} \\
\hline & & & & Meteorology & $\begin{array}{l}\text { Air } \\
\text { quality }\end{array}$ & \\
\hline $\begin{array}{l}\text { WRF V3.2 } \\
\text { Reference } \\
\text { Configuration } \\
\text { [23] }\end{array}$ & & & & $\begin{array}{l}\text { Surface and } \\
\text { vertical profiles }\end{array}$ & -- & $\begin{array}{l}\text { QNSE } \\
\text { YSU }\end{array}$ \\
\hline $\begin{array}{l}\text { This } \\
\text { assessment }\end{array}$ & $-0.2^{\circ}$ & $\begin{array}{l}\text { Quito, } \\
\text { Ecuador } \\
\end{array}$ & $\begin{array}{l}\text { Oct. 1-28, } \\
2014\end{array}$ & 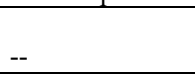 & $\mathrm{CO}$ & $\begin{array}{l}\text { QNSE } \\
\text { MYJ }\end{array}$ \\
\hline $\begin{array}{l}6], \text { WRF } \\
\text { V3.4.1 }\end{array}$ & $41.1^{\circ}$ & $\begin{array}{l}\text { Great Salt } \\
\text { Lake, US }\end{array}$ & $\begin{array}{l}\text { Autumn 2012, } \\
\text { Spring } 2013\end{array}$ & $\begin{array}{l}\text { Near surface } \\
\text { temperature }\end{array}$ & -- & QNSE \\
\hline $\begin{array}{l}\text { [5], WRF } \\
\text { V3.4.1 }\end{array}$ & $38^{\circ}$ & $\begin{array}{l}\text { Athens, } \\
\text { Greece }\end{array}$ & Summer 2014 & $\begin{array}{l}\text { Potential } \\
\text { temperature }\end{array}$ & -- & MYJ \\
\hline $\begin{array}{l}\text { [24], WRF } \\
\text { V3.2 }\end{array}$ & $12.5^{\circ}$ & $\begin{array}{l}\text { Kalpakkam, } \\
\text { India }\end{array}$ & $\begin{array}{l}\text { Sep. 22-24, } \\
2010\end{array}$ & $\begin{array}{l}\text { Various PBL } \\
\text { quantities }\end{array}$ & -- & $\begin{array}{l}\text { MYN } \\
\text { YSU }\end{array}$ \\
\hline [7], WRF V3.5 & $29.7^{\circ}$ & $\begin{array}{l}\text { Houston, } \\
\text { US }\end{array}$ & Oct. 5, 2006 & 1 & $\mathrm{O} 3$ & YSU \\
\hline
\end{tabular}

The diversity of results reported in the literature highlights the need for assessment. The direct use of the PBL schemes of a proposed RC does not necessarily correspond to the best performance for a specific region.

QNSE, the scheme with the best performance in this assessment, provides realistic depiction of potential temperature, PBL height and kinematic profiles for stable conditions [4]. Maximum 1-hour and 8-hour mean $\mathrm{CO}$ concentrations typically take place during the morning (07h00-08h00). Thus, stable conditions are associated with this time, which potentially explains the better performance of this scheme in comparison with the others. Because QNSE is a local scheme, it neglects the effects of large eddies. Hence, its performance could worsen in modeling PBL heights or O3 concentrations at midday, when atmospheric conditions are very unstable and the influence of large eddies is strong. This 
also could explain why the YSU, a nonlocal scheme, showed the best performance in the intercomparison of $\mathrm{O} 3$ modeling in Houston [7].

As the performance of the ensemble scenario (81.1\%) was slightly higher in comparison with QNSE scheme (78.9\%), it suggests that for the DMQ, it is enough the use of this scheme-with less computational resources-for modeling $\mathrm{CO}$ dispersion and potentially other primary pollutants, whose larger concentrations are associated with stable conditions of the atmosphere. In case of other pollutants as O3, similar assessments should be done. For these reasons, the DMQ requires more assessments of the PBL schemes, covering other periods, pollutants and meteorological variables.

\section{ACKNOWLEDGEMENT}

Our thanks to Hilary Brumberg, who checked the English grammar. Simulations were performed at the High Performance Computing system at the Universidad San Francisco de Quito.

\section{REFERENCES}

[1] Stull, R., An Introduction to Boundary Layer Meteorology, Kluwer Academic: Dordrecht, The Netherlands, 666 pp., 1988.

[2] Stull, R., Meteorology for Scientist and Engineers, 2nd ed., Brooks/Cole Thomson Learning: USA, 502 pp., 2000.

[3] Stensrud, D., Parameterization Schemes, Keys to Understanding Numerical Weather Prediction Models, Cambridge University Press: New York, 459 pp., 2007.

[4] Cohen, A., Cavallo, S., Coniglio, M. \& Brooks, H., A review of planetary boundary layer parameterization schemes and their sensitivity in simulating southeastern U.S. cold season weather environments. Journal Weather and Forecasting, American Meteorological Society, 30, pp. 591-612, 2015.

[5] Banks, R., et al., Sensitivity of boundary-layer variables to PBL schemes in the WRF model based on surface meteorological observations, lidar, and radiosondes during the HygrA-CD campaign. Atmospheric Research, 176-177, pp. 185-201, 2016.

[6] Dimitrova, R., et al., Assessment of planetary boundary-layer schemes in the weather research and forecasting mesoscale model using MATERHORN field data. Boundary-Layer Meteorology, 176-177, pp. 185-201, 2016.

[7] Cuchiara, G., Li, X., Carvalho, J. \& Rappenglück, B., Intercomparison of planetary boundary layer parameterization and its impacts on surface ozone concentrations in the WRF/Chem model for a case study in Houston/Texas. Atmospheric Environment, 96, pp. 175-186, 2014.

[8] CORPAIRE, Inventario de Emisiones del Distrito Metropolitano de Quito Año 2007, Corporación Municipal para el Mejoramiento del Aire de Quito, 2009.

[9] Vega, D. \& Parra, R., Caracterización de la intensidad media diaria y de los perfiles horarios del tráfico vehicular del Distrito Metropolitano de Quito. Avances en Ciencias e Ingeniería, 6(2), pp. C40-C45, 2014.

[10] Vallero, D., Fundamentals of Air Pollution, $4^{\text {th }}$ ed., Academic Press, 942 pp., 2008.

[11] Jacob, D., Introduction to Atmospheric Chemistry, Princeton University Press: New Jersey, 266 pp., 1999.

[12] Vega, D., Ocaña, L. \& Parra, R., Inventario de emisiones atmosféricas del tráfíco vehicular en el Distrito Metropolitano de Quito Año base 2012. Avances en Ciencias e Ingeniería, 7(2), pp. C82-C90, 2015.

[13] Weather Research and Forecasting Model, http://wrf-model.org 
[14] NCEP, NCEP FNL Operational Model Global Tropospheric Analyses, continuing from July 1999, Research Data Archive at the National Center for Atmospheric Research, Computational and Information Systems Laboratory, http://rda.ucar.edu/datasets/ds083.2

[15] Skamarock, W., et al., A Description of the Advanced Research WRF Version 3. NCAR/TN-475+STR. NCAR Technical Note. Mesoscale and Microscale Meteorology Division. National Center for Atmospheric Research, Boulder, CA, 2008.

[16] Hong, S., Noh, S. \& Dudhia, J., A new vertical diffusion package with an explicit treatment of entrainment processes. Monthly Weather Review, 134, pp. 2318-2341, 2006.

[17] Janjic, Z., The step-mountain eta coordinate model: further developments of the convection, viscous sublayer, and turbulence closure schemes. Monthly Weather Review, 122, pp. 927-945, 1994.

[18] Sukoriansky, S., Galperin, B. \& Perov, V., Application of a new spectral theory of stably stratified turbulence to the atmospheric boundary layer over sea ice. Boundary-Layer Meteorology, 177, pp. 231-257, 2005.

[19] Nakanishi, M. \& Niino, H., An improved Mellor-Yamada level-3 model: its numerical stability and application to a regional prediction of advection fog. Boundary-Layer Meteorology, 119, pp. 397-407, 2006.

[20] Bougeault, P. \& Lacarrère, P., Parameterization of orography-induced turbulence in a Mesobeta-scale model. Monthly Weather Review, 117, pp. 1872-1890, 1989.

[21] World Health Organization, Air Quality Guidelines for Europe, 2nd ed., WHO Regional Publications, European Series, No. 91, 2000.

[22] European Environment Agency, The Application of Models under the European Union's Air Quality Directive: A Technical Reference Guide, EEA Technical Report No. 10/2011.

[23] Developmental Testbed Center, www.dtcenter.org

[24] Hariprasad, K., Srinivas, C., Bagavath Singh, A., Vijaya Bhaskara Rao, S., Baskaran, R. \& Venkatraman, B., Numerical simulation and intercomparison of boundary layer structure with different PBL schemes in WRF using experimental observations at a tropical site. Atmospheric Research, 145-146, pp. 27-44, 2014. 